ECCOMAS

Proceedia
COMPDYN 2021

$8^{\text {th }}$ ECCOMAS Thematic Conference on Computational Methods in Structural Dynamics and Earthquake Engineering

M. Papadrakakis, M. Fragiadakis (eds.)

\title{
THE USE OF AN INTEGRATED APPROACH FOR BUILDING INVENTORY AND EFFECTS ON RISK ESTIMATIONS AT THE TERRITORIAL SCALE
}

\author{
M. Polese ${ }^{1}$, M. Di Ludovico ${ }^{1}$, G. Tocchi and A. Prota ${ }^{1}$ \\ ${ }^{1}$ Department of Structures for Engineering and Architecture, University of Naples Federico II \\ Via Claudio 21, 80125, Naples, Italy \\ e-mail:mapolese@unina.it; diludovi@unina.it; gabriella.tocchi@unina.it; \\ andrea.prota@unina.it
}

\begin{abstract}
Large-scale seismic risk assessment is probably the most appropriate tool for investigating the consequences of earthquakes in a region of interest. Most of the existing risk-oriented studies focus on the seismic hazard evaluation and vulnerability assessment, while fewer efforts were performed in evaluating the influence of exposure modelling. The large-scale building inventory is generally conducted by relying on readily available sources of information, such as databases based on census data. However, the information contained in census databases are often limited to poor level data, such as building construction material, construction age and (not always available) the storey number. The use of inventory data for large scale application requires suitable rules to assign buildings typologies to vulnerability classes, that is an exposure model. Most of the existing exposure models are calibrated on building typological data available from post-earthquake survey data and therefore are based on data from specific geographic areas, namely the ones hit by damaging earthquakes. It is known that the distribution of building typologies can vary greatly for different areas of a country and the availability of construction material in the area. Furthermore, the evolution of construction techniques and the codes in force at the time of construction may affect the presence of a particular building's typology rather that another one. This study aims to evaluate the influence of a better knowledge level of the building environment on seismic risk at regional scale, investigating the variability of masonry building typologies distribution. The application is presented for two different Italian regions, showing that an improved characterization of regional vulnerability may strongly influence the impacts in terms of risk estimations.
\end{abstract}

Keywords: exposure, vulnerability, inventory, local building typologies, Cartis 


\section{INTRODUCTION}

In large scale seismic risk assessment, the buildings are clustered in relevant vulnerability classes based on the behavior that is expected during a seismic event, for which different vulnerability functions are defined. A common vulnerability classification is given by the European Macroseismic Scale EMS'98 [1], that categorizes buildings in 6 vulnerability classes (from A to F), based on the type of vertical structures, i.e. the construction material and code design level. Other vulnerability models identify vulnerability classes based on the construction material (masonry, reinforced concrete, steel, wood) taking into account as well other structural and non-structural elements features (e.g. [2]-[4]).

The distribution of buildings within the vulnerability classes in each territorial unit of analysis is given by building inventory. Different sources of information on people and residential buildings are available with global coverage at national and sub-national level (e.g. [5]-[7]); however, in order to compile building inventory Census database is often the primary employed source, thanks to their availability and diffusion on whole national territory. In Italy, census data on population and buildings, allowing to count building numerousness in terms of construction material, number of storeys and construction age, are produced by ISTAT, the national statistical institute. The data for each census tracts are available in aggregated form for privacy reasons, but the disaggregated census data on buildings are also available at provincial or municipality level, as shown in [8]-[9] and [10].

In general, to compile a building inventory at territorial scale starting from census data, a suitable exposure model is required to associate the building typology to vulnerability classes defined according to a vulnerability model. In the methodology adopted within last National Risk Assessment (NRA) for Italy [11], the exposure modelling defines the rules to assign building typology identified by ISTAT to EMS'98 vulnerability classes. Moreover, the methodology allowed to evaluate the risk by combination of the results obtained adopting different vulnerability/exposure models (VEM). Generally, exposure models may be calibrated based on building typological data available from post-earthquake surveys in Italy (e.g. [13] and [14]) or other available building-by-building survey databases (as in [15]) and eventually integrating them with expert judgment (e.g. [16]).

However, due to the high costs and time required, building-by-building survey campaign are generally carried out for limited areas in a country, such as urban districts or small municipalities, and the ones conducted after a noteworthy seismic event usually completely inspect only the municipalities with higher macroseismic intensity [17].

Thus, the exposure model used in national or sub-national risk assessment may be calibrated on data referred to a specific geographic area. However, the buildings' characteristics may be not the same for different areas of a country, likely due to variability in construction material diffusion and in construction techniques use for different regions.

Mostly for unreinforced masonry buildings, the type of vertical structure (e.g. regular, irregular, round stone, regular stone etc.), that has a clear influence on seismic vulnerability, may vary significantly: the type of stones can be influenced by the geography of the territory (e.g. the presence of quarries, waterways and volcanic areas) and in turn construction techniques are influenced by the type of stones, because some types of stones are better suited to be cut into square blocks. In Italy, in inland areas near to Apennine limestone is widespread while bricks are typical of the Adriatic coast and tuff of volcanic areas. This could explain the reason of large presence of irregular layout structures in the internal areas of the country and the presence of regular layout masonry structures in the areas characterized by the presence of bricks, tuff or travertine, as shown in [18]-[20]. 
A recent approach for the compiling of large-scale inventories is provided by Cartis [21], an interview-based form developed within "Territorial Themes" ReLUIS project financed by the Italian Civil Protection Department. The Cartis approach allows to rapidly survey ordinary building typologies in urban area, collecting information on buildings features useful for the building vulnerability classification. In this paper, we propose the use of Cartis database to improve the exposure modelling at regional scale. Adopting the methodology proposed in [22] and briefly recalled in the next paragraphs, the effects of the improved vulnerability characterization on risk assessment are evaluated for two Italian regions. Two exposure/vulnerability model recently proposed in Italy for unreinforced masonry buildings are adopted and the damage and risk assessment obtained from the original vulnerability/exposure models and from the ones updated through the Cartis-based inventory area compared. It will be shown that not negligible changes of the impacts may be observed, also depending on the analyzed region.

\section{THE ADOPTED VULNERABILITY/EXPOSURE MODELS}

With the aim to investigate the effect of different typological distribution on the vulnerability assessment at the regional scale, two empirical vulnerability/exposure models that were recently proposed for masonry type buildings are adopted. The model proposed by Del Gaudio et al. [3], referred to as DG2019, is based on the statistical treatment of typological and damage data of masonry buildings damaged after the 2009 L'Aquila earthquake. The authors propose empirical based lognormal fragility curves for 14 masonry buildings classes, defined based on the combination of vertical structures (regular layout or good quality, irregular layout or poor quality structure with or without tie rods/beams) and horizontal structures (vaults with or without tie rods, beams with flexible, semi-rigid or rigid slabs), as shown in Table 1. Moreover, a set of fragility curves directly referred to construction age intervals, usable with a building classification based on census data, are also proposed. These age-dependent fragility curves are derived by a linear combination of the 14 sets of typological fragility curves, using the percentage of occurrence of each class within the 8 times intervals defined by ISTAT ( $<$ 1919, 1919-1945, 1946-1961, 1962-1971, 1972-1981, 1982-1991, 1991-2001, > 2001) reported in Table 1 as linear combination coefficients. To find out the distribution of buildings belonging to different age ranges, the data derived from the sample of 22,618 residential masonry buildings surveyed after L'Aquila earthquake are used. From this database analysis, it can be noted that most of the buildings built before 1945 are characterized by irregular layout (class $4 \mathrm{~B}$ and $5 \mathrm{~B}$ in Table 1), whit high percentage of vaults in oldest buildings (class 23BC), while modern buildings are characterized by regular layout and rigid floors. 
Table 1 - Occurrence percentages of vulnerability classes into 8 time intervals, defined by [3].

\begin{tabular}{|c|c|c|c|c|c|c|c|c|c|c|c|c|c|c|}
\hline & \multicolumn{2}{|c|}{$\begin{array}{c}\begin{array}{c}\text { Vaults with or w/o tie } \\
\text { rods }\end{array} \\
\end{array}$} & \multicolumn{4}{|c|}{$\begin{array}{l}\text { Beams with } \\
\text { Flexible slab } \\
\end{array}$} & \multicolumn{4}{|c|}{$\begin{array}{c}\text { Beams with } \\
\text { Semi-rigid slab } \\
\end{array}$} & \multicolumn{4}{|c|}{$\begin{array}{l}\text { Beams with } \\
\text { Rigid slab }\end{array}$} \\
\hline & \multirow[t]{2}{*}{$\begin{array}{c}\text { Irregular } \\
\text { layout or } \\
\text { poor } \\
\text { quality }\end{array}$} & \multirow[t]{2}{*}{$\begin{array}{l}\text { Regular } \\
\text { layout or } \\
\text { good } \\
\text { quality }\end{array}$} & \multicolumn{2}{|c|}{$\begin{array}{l}\text { Irregular layout } \\
\text { or poor quality }\end{array}$} & \multicolumn{2}{|c|}{$\begin{array}{c}\text { Regular layout } \\
\text { or } \\
\text { good quality }\end{array}$} & \multicolumn{2}{|c|}{$\begin{array}{l}\text { Irregular layout } \\
\text { or poor quality }\end{array}$} & \multicolumn{2}{|c|}{$\begin{array}{l}\text { Regular layout } \\
\text { or good quality }\end{array}$} & \multicolumn{2}{|c|}{$\begin{array}{l}\text { Irregular layout } \\
\text { or poor quality }\end{array}$} & \multicolumn{2}{|c|}{$\begin{array}{l}\text { Regular layout } \\
\text { or good quality }\end{array}$} \\
\hline & & & $\begin{array}{l}\text { W/o tie } \\
\text { rods or } \\
\text { tie } \\
\text { beams } \\
4 \mathrm{~B} \\
\end{array}$ & $\begin{array}{c}\text { With } \\
\text { tie } \\
\text { rods or } \\
\text { tie } \\
\text { beams } \\
4 \mathrm{C} \\
\end{array}$ & $\begin{array}{c}\text { W/o tie } \\
\text { rods or } \\
\text { tie } \\
\text { beams }\end{array}$ & $\begin{array}{c}\text { With } \\
\text { tie } \\
\text { rods or } \\
\text { tie } \\
\text { beams } \\
4 \mathrm{E} \\
\end{array}$ & $\begin{array}{c}\text { W/o tie } \\
\text { rods or } \\
\text { tie } \\
\text { beams }\end{array}$ & $\begin{array}{c}\text { With } \\
\text { tie } \\
\text { rods or } \\
\text { tie } \\
\text { beams } \\
5 \mathrm{C} \\
\end{array}$ & $\begin{array}{c}\text { W/o tie } \\
\text { rods or } \\
\text { tie } \\
\text { beams }\end{array}$ & $\begin{array}{c}\text { With } \\
\text { tie } \\
\text { rods or } \\
\text { tie } \\
\text { beams } \\
5 E \\
\end{array}$ & $\begin{array}{c}\text { W/o tie } \\
\text { rods or } \\
\text { tie } \\
\text { beams }\end{array}$ & $\begin{array}{c}\text { With } \\
\text { tie } \\
\text { rods or } \\
\text { tie } \\
\text { beams } \\
6 \mathrm{C} \\
\end{array}$ & $\begin{array}{c}\text { W/o tie } \\
\text { rods or } \\
\text { tie } \\
\text { beams }\end{array}$ & $\begin{array}{c}\text { With } \\
\text { tie } \\
\text { rods or } \\
\text { tie } \\
\text { beams } \\
6 \mathrm{E} \\
\end{array}$ \\
\hline$<19$ & $22 \%$ & $3 \%$ & $25 \%$ & $5 \%$ & $2 \%$ & $1 \%$ & $21 \%$ & $6 \%$ & $4 \%$ & $2 \%$ & $3 \%$ & $2 \%$ & $1 \%$ & $2 \%$ \\
\hline $19-45$ & $8 \%$ & $2 \%$ & $23 \%$ & $3 \%$ & $4 \%$ & $1 \%$ & $23 \%$ & $6 \%$ & $9 \%$ & $4 \%$ & $4 \%$ & $3 \%$ & $3 \%$ & $7 \%$ \\
\hline $46-61$ & $2 \%$ & $1 \%$ & $9 \%$ & $1 \%$ & $4 \%$ & $1 \%$ & $17 \%$ & $6 \%$ & $13 \%$ & $8 \%$ & $5 \%$ & $7 \%$ & $7 \%$ & $20 \%$ \\
\hline $62-71$ & $1 \%$ & $0 \%$ & $3 \%$ & $1 \%$ & $6 \%$ & $1 \%$ & $4 \%$ & $3 \%$ & $9 \%$ & $9 \%$ & $3 \%$ & $5 \%$ & $12 \%$ & $43 \%$ \\
\hline $72-81$ & $0 \%$ & $0 \%$ & $2 \%$ & $0 \%$ & $4 \%$ & $1 \%$ & $2 \%$ & $1 \%$ & $6 \%$ & $8 \%$ & $1 \%$ & $2 \%$ & $11 \%$ & $62 \%$ \\
\hline $\begin{array}{c}82-91 \\
92-\end{array}$ & $0 \%$ & $0 \%$ & $2 \%$ & $0 \%$ & $6 \%$ & $2 \%$ & $2 \%$ & $1 \%$ & $5 \%$ & $6 \%$ & $2 \%$ & $2 \%$ & $11 \%$ & $62 \%$ \\
\hline 2001 & $2 \%$ & $1 \%$ & $4 \%$ & $1 \%$ & $7 \%$ & $4 \%$ & $3 \%$ & $2 \%$ & $5 \%$ & $5 \%$ & $2 \%$ & $2 \%$ & $10 \%$ & $53 \%$ \\
\hline$>2001$ & $3 \%$ & $0 \%$ & $3 \%$ & $1 \%$ & $5 \%$ & $5 \%$ & $4 \%$ & $3 \%$ & $3 \%$ & $9 \%$ & $3 \%$ & $2 \%$ & $6 \%$ & $52 \%$ \\
\hline
\end{tabular}

The second model, proposed by Rosti et al. [23] referred to as RO2020, was derived considering the L'Aquila 2009 and Irpinia 1980 post earthquakes data. Eight building typologies were identified, based on quality of the masonry fabric (i.e. irregular layout or poor-quality masonry, regular layout and good-quality masonry), in-plane flexibility of diaphragms (i.e. flexible, rigid), presence (or absence) of connecting devices. These typologies were fused into three vulnerability classes (A: high vulnerability, B: medium vulnerability, C1: low vulnerability) based on classification rules proposed by Rota et al. [4], reported in Table 2. As one of the purposes of this study was to implement the model using IRMA platform [12] for its possible application for national risk assessment in Italy [11], the authors proposed an exposure model that defines the rules to assign the percentage of each census-based typologies for masonry buildings (defined based on construction age $-<1919,1919-45,1946-61,1962-71$, 1972-81, > 1981- and height level - L and MH) into the three vulnerability classes A, B and C1.

Table 2 - Definition of vulnerability classes based on type of vertical and horizontal structures and presence of connection devices, as reported in [4]

\begin{tabular}{|c|c|c|c|c|}
\hline \multirow[t]{2}{*}{ Horizontal structure } & \multicolumn{2}{|c|}{ Irregular texture or poor quality masonry } & \multicolumn{2}{|c|}{$\begin{array}{l}\text { Regular texture and good quality mason- } \\
\text { ry }\end{array}$} \\
\hline & $\begin{array}{c}\text { w/o connecting } \\
\text { device }\end{array}$ & $\begin{array}{c}\text { with connecting } \\
\text { device }\end{array}$ & $\begin{array}{c}\text { w/o connecting } \\
\text { device }\end{array}$ & $\begin{array}{c}\text { with connecting } \\
\text { device }\end{array}$ \\
\hline Flexible & $\mathrm{A}$ & $\mathrm{A}$ & $\mathrm{B}$ & $\mathrm{C} 1$ \\
\hline Semi-rigid & A & A & $\mathrm{B}$ & $\mathrm{C} 1$ \\
\hline Rigid & $\mathrm{A}$ & B & $\mathrm{C} 1$ & $\mathrm{C} 1$ \\
\hline Vaults & A & $\mathrm{B}$ & $\mathrm{C} 1$ & $\mathrm{C} 1$ \\
\hline
\end{tabular}

This exposure model was calibrated through an optimization problem finalized to minimize the difference among a set of empirical fragility curves, derived by the sole dataset of masonry buildings damaged after 2009 L'Aquila earthquake, and the fragility curves previously derived for $\mathrm{A}, \mathrm{B}$ and $\mathrm{C} 1$ vulnerability classes. The resulting exposure matrix is reported in Table 3. 
Table 3 - Composition of the masonry building stock in terms of percentages of macro-categories belonging to the different vulnerability classes, according to [23]

\begin{tabular}{ccccccc} 
Class of height & \multicolumn{3}{c}{ Low } & \multicolumn{3}{c}{ Medium-High } \\
\hline Vulnerability class & A-L & B-L & C1-L & A-MH & B-MH & C1-MH \\
\hline$<\mathbf{1 9}$ & $86 \%$ & $0 \%$ & $14 \%$ & $97 \%$ & $0 \%$ & $3 \%$ \\
$\mathbf{1 9 - 4 5}$ & $45 \%$ & $44 \%$ & $11 \%$ & $22 \%$ & $78 \%$ & $0 \%$ \\
$\mathbf{4 6 - 6 1}$ & $9 \%$ & $59 \%$ & $32 \%$ & $0 \%$ & $75 \%$ & $25 \%$ \\
$\mathbf{6 2 - 7 1}$ & $5 \%$ & $4 \%$ & $91 \%$ & $0 \%$ & $18 \%$ & $82 \%$ \\
$\mathbf{7 2 - 8 1}$ & $0 \%$ & $0 \%$ & $100 \%$ & $0 \%$ & $0 \%$ & $100 \%$ \\
$\mathbf{8 2 - 9 1}$ & $0 \%$ & $0 \%$ & $100 \%$ & $0 \%$ & $0 \%$ & $100 \%$ \\
\hline
\end{tabular}

\section{EXPOSURE MODELLING: A CARTIS-BASED APPROACH}

The proposed methodology relies on Cartis form's information to re-calibrate the exposure models in different Italian regions. The $1^{\text {st }}$ level "Cartis" form is an interview-based form finalized to the survey of ordinary building typologies in sub-areas of the town denominated Town Compartments TC, characterized by prevailing homogeneity of the built environment in terms of initial period of construction and/or constructive structural characteristics. Using Cartis approach is possible to detect buildings features having strong influence on seismic behavior, allowing a more refined classification for buildings. In addition to age of construction and number of storeys, for masonry building the type of masonry (e.g. irregular layout masonry or regular layout with square stones or bricks), the horizontal slab type (e.g. flexible, rigid or semi-rigid slabs), the type of vaults (if present) and the presence of tie rods or tie beams are some of the vulnerability factors considered in the form. For each TC the form allows to detect up to four different typologies for masonry buildings (MUR1, MUR2, MUR3, MUR4) and four for RC buildings (CAR1, CAR2, CAR3, CAR4).

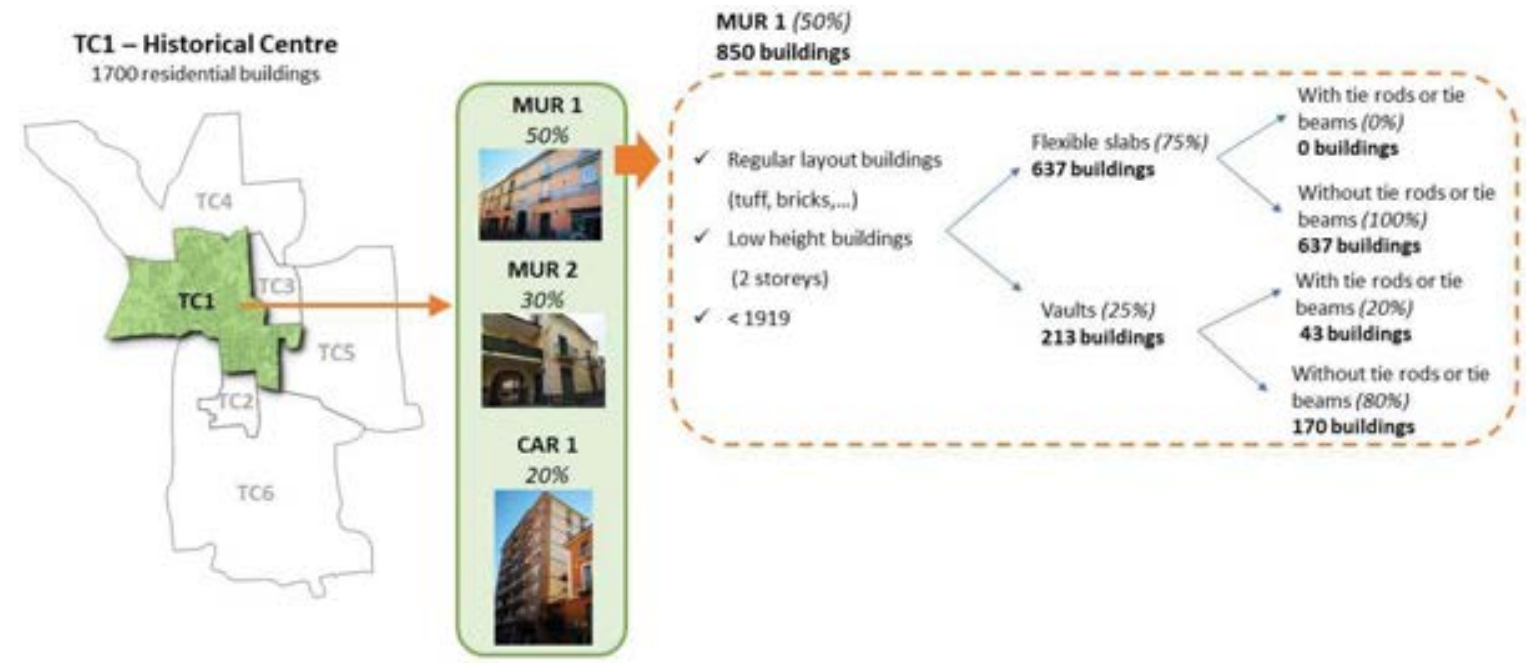

Figure 1 - Town Compartments for a town in the south of Italy and an example of buildings distribution for TC1, based on the related percentages reported in Cartis.

For each typology, the incidence percentages of the typology on the buildings in the TC are given. Therefore, given the total numbers of buildings in each TC, it is possible to derive the number of building belonging to different building typologies, and, consequently, considering all TCs in a town, the inventory at municipal level can be obtained. An example of the proce- 
dure to derive the number of building for a masonry typology in a town compartment is reported in Figure 1.

Starting from the inventory compiled in towns where Cartis form is available, the occurrence percentage of building typologies at regional scale can be derived. Once the number of buildings belonging to defined structural types is obtained, it is possible to group them into vulnerability classes, according to the adopted vulnerability model.

In [22], based on the availability of Cartis-based inventory, a methodology for exposure modelling was proposed, that can be reassumed in the following steps:

a) Compiling of Cartis-based inventory at urban scale, for all the towns where Cartis information is available.

b) Deriving statistical distribution of building typologies at regional scale considering all the towns in the region for which Cartis-based inventory was compiled.

c) Recalibration of exposure matrix with the percental distribution obtained by Cartisbased inventories, according to the vulnerability classes considered by the adopted vulnerability model.

Note that the reliability of the procedure is affected by the percentage of investigated towns as well as by their representativeness in terms of building and population number in a region.

As explained in [22], two slightly different approaches for the recalibration of the DG2019 and RO2020 models are applied. In DG2019 the age-dependent fragility curves to use with available ISTAT data was obtained by a linear combination of the fragility curves relative to the 14 building classes; therefore, after the recalibration of the exposure matrix a new set of age-dependent fragility curve has to be derived to evaluate the risk starting by census data. Differently, according to RO2020 model, only the exposure matrix was recalibrated, without modification of the fragility curves used for risk calculation. It is worth noting that the exposure matrices in DG2019 and RO2020 were obtained by statistical analysis of typological data relative to the sole buildings that were inspected after the 2009 L'Aquila earthquake. Thus, these matrices represent the typological distribution of a specific region (i.e. Abruzzo region). Therefore, a more accurate calibration procedure may improve the vulnerability characterization at regional level and consequently may affect the estimation of expected damage and impacts.

\section{APPLICATION FOR TWO ITALIAN REGIONS}

The proposed procedure is applied for two Italian regions: Toscana and Veneto. In Toscana region 59 towns were surveyed through Cartis form, that represent about $22 \%$ of Toscana municipalities and $10 \%$ of regional inhabitants. In Veneto 35 towns were surveyed, representing the $6 \%$ of the municipalities and covering approximately the $11 \%$ of regional population.

According to the procedure previously described, the Cartis-based inventory is compiled for all the towns surveyed by Cartis form. Assuming the surveyed municipalities representative of the entire region, the percentage distribution of building typologies at regional level is obtained. It is worth noting that the Cartis database partially cover the whole regional territory, so this simplifying hypothesis could affect the reliability of estimations at regional scale. However, the present study represents a preliminary application to investigate the variability of vulnerability characterization at regional level and the results are expected to be updated when Cartis form on other municipalities will be compiled. 


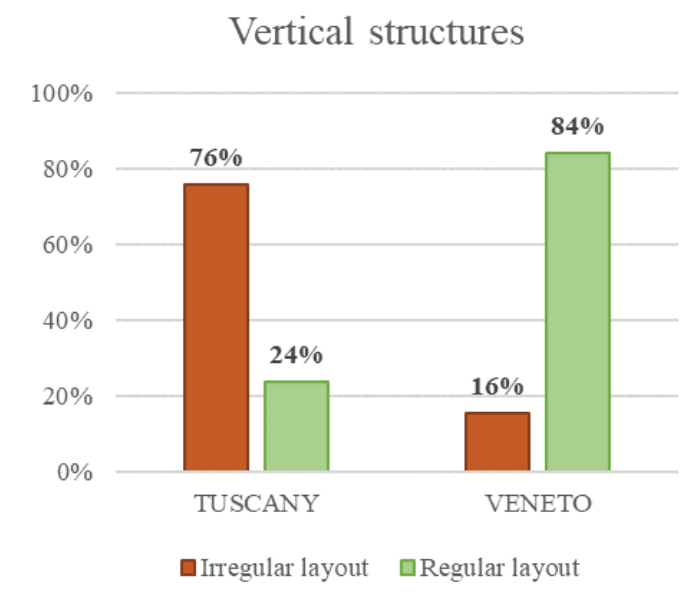

Figure 2 - Diffusion of the vertical (irregular or regular layout) types on masonry building stock at regional scale, derived by Cartis - based inventory.

The analysis of the regional inventories shows very different distribution of masonry building typologies. In Toscana irregular layout vertical structures are widespread, representing about $76 \%$ of masonry buildings, while in Veneto this typology characterizes just the $16 \%$ of the total, see Figure 2. Regarding horizontal structures type, the major difference between regional inventories is about the diffusion of semi-rigid slab type in irregular layout structures, about $36 \%$ in Toscana and almost absent in Veneto (2\%), see Figure 3.

Once obtained the number of buildings with specific structural features (e.g. the number of masonry buildings with regular layout and vaults without tie rods), it's possible to group them into vulnerability classes according to DG2019 and RO2020 models and recalibrate the relative exposure matrices.

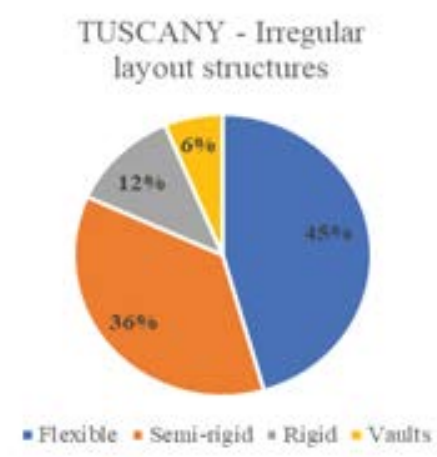

(a)

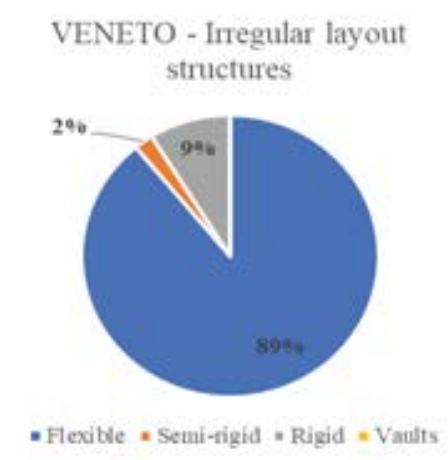

(b)

Figure 3- Diffusion of horizontal structure types for irregular layout buildings according to Cartis-based inventory, for Tuscany (a) and Veneto region (b).

The comparison with the DG2019 exposure model shows a considerable increase of irregular layout masonry structures in Tuscany for first and second time intervals $(<1919,1919$ 1945) (see Table 4). In particular, poor quality masonry structures without tie rods or tie beams and with flexible slabs (4B) and semi-rigid slabs (5B) are more widespread in Tuscany than in Abruzzo, according to the DG2019 matrix. Moreover, this type of structures represents a not negligible percentage of more recent built buildings. 
Table 4 -DG2019 exposure matrix derived by Cartis-based inventory, for Tuscany region.

\begin{tabular}{|c|c|c|c|c|c|c|c|c|c|c|c|c|c|c|}
\hline & \multicolumn{2}{|c|}{$\begin{array}{c}\text { Vaults with or w/o tie } \\
\text { rods } \\
\end{array}$} & \multicolumn{4}{|c|}{$\begin{array}{l}\text { Beams with } \\
\text { Flexible slab } \\
\end{array}$} & \multicolumn{4}{|c|}{$\begin{array}{c}\text { Beams with } \\
\text { Semi-rigid slab } \\
\end{array}$} & \multicolumn{4}{|c|}{$\begin{array}{l}\text { Beams with } \\
\text { Rigid slab }\end{array}$} \\
\hline & \multirow[t]{2}{*}{$\begin{array}{c}\text { Irregular } \\
\text { layout or } \\
\text { poor } \\
\text { quality }\end{array}$} & \multirow[t]{2}{*}{$\begin{array}{c}\text { Regular } \\
\text { layout or } \\
\text { good } \\
\text { quality }\end{array}$} & \multicolumn{2}{|c|}{$\begin{array}{l}\text { Irregular layout } \\
\text { or poor quality }\end{array}$} & \multicolumn{2}{|c|}{$\begin{array}{c}\text { Regular layout } \\
\text { or } \\
\text { good quality }\end{array}$} & \multicolumn{2}{|c|}{$\begin{array}{l}\text { Irregular layout } \\
\text { or poor quality }\end{array}$} & \multicolumn{2}{|c|}{$\begin{array}{l}\text { Regular layout } \\
\text { or good quality }\end{array}$} & \multicolumn{2}{|c|}{$\begin{array}{l}\text { Irregular layout } \\
\text { or poor quality }\end{array}$} & \multicolumn{2}{|c|}{$\begin{array}{l}\text { Regular layout } \\
\text { or good quality }\end{array}$} \\
\hline & & & $\begin{array}{c}\text { W/o tie } \\
\text { rods or } \\
\text { tie } \\
\text { beams }\end{array}$ & $\begin{array}{c}\text { With } \\
\text { tie } \\
\text { rods or } \\
\text { tie } \\
\text { beams } \\
4 \mathrm{C} \\
\end{array}$ & $\begin{array}{c}\text { W/o tie } \\
\text { rods or } \\
\text { tie } \\
\text { beams }\end{array}$ & $\begin{array}{c}\text { With } \\
\text { tie } \\
\text { rods or } \\
\text { tie } \\
\text { beams } \\
4 \mathrm{E} \\
\end{array}$ & $\begin{array}{c}\text { W/o tie } \\
\text { rods or } \\
\text { tie } \\
\text { beams }\end{array}$ & $\begin{array}{c}\text { With } \\
\text { tie } \\
\text { rods or } \\
\text { tie } \\
\text { beams } \\
5 \mathrm{C} \\
\end{array}$ & $\begin{array}{c}\text { W/o tie } \\
\text { rods or } \\
\text { tie } \\
\text { beams }\end{array}$ & $\begin{array}{c}\text { With } \\
\text { tie } \\
\text { rods or } \\
\text { tie } \\
\text { beams } \\
5 E \\
\end{array}$ & $\begin{array}{c}\text { W/o tie } \\
\text { rods or } \\
\text { tie } \\
\text { beams }\end{array}$ & $\begin{array}{c}\text { With } \\
\text { tie } \\
\text { rods or } \\
\text { tie } \\
\text { beams } \\
6 \mathrm{C} \\
\end{array}$ & $\begin{array}{c}\text { W/o tie } \\
\text { rods or } \\
\text { tie } \\
\text { beams } \\
\text { 6D } \\
\end{array}$ & 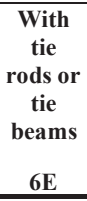 \\
\hline$<19$ & $8 \%$ & $1 \%$ & $43 \%$ & $11 \%$ & $5 \%$ & $0 \%$ & $23 \%$ & $6 \%$ & $0 \%$ & $0 \%$ & $1 \%$ & $0 \%$ & $1 \%$ & $0 \%$ \\
\hline $19-45$ & $3 \%$ & $1 \%$ & $21 \%$ & $5 \%$ & $7 \%$ & $1 \%$ & $41 \%$ & $9 \%$ & $1 \%$ & $0 \%$ & $7 \%$ & $2 \%$ & $3 \%$ & $0 \%$ \\
\hline $46-61$ & $0 \%$ & $1 \%$ & $12 \%$ & $5 \%$ & $8 \%$ & $3 \%$ & $31 \%$ & $13 \%$ & $7 \%$ & $3 \%$ & $7 \%$ & $3 \%$ & $5 \%$ & $2 \%$ \\
\hline $62-71$ & $0 \%$ & $0 \%$ & $1 \%$ & $1 \%$ & $1 \%$ & $1 \%$ & $1 \%$ & $2 \%$ & $1 \%$ & $2 \%$ & $12 \%$ & $16 \%$ & $22 \%$ & $40 \%$ \\
\hline $72-81$ & $0 \%$ & $0 \%$ & $1 \%$ & $1 \%$ & $1 \%$ & $2 \%$ & $1 \%$ & $1 \%$ & $1 \%$ & $3 \%$ & $10 \%$ & $18 \%$ & $16 \%$ & $46 \%$ \\
\hline $82-91$ & $0 \%$ & $0 \%$ & $0 \%$ & $0 \%$ & $1 \%$ & $3 \%$ & $0 \%$ & $0 \%$ & $1 \%$ & $2 \%$ & $12 \%$ & $6 \%$ & $14 \%$ & $61 \%$ \\
\hline $\begin{array}{c}92- \\
2001\end{array}$ & $0 \%$ & $0 \%$ & $0 \%$ & $0 \%$ & $68 \%$ & $1 \%$ & $0 \%$ & $0 \%$ & $1 \%$ & $0 \%$ & $23 \%$ & $0 \%$ & $7 \%$ & $0 \%$ \\
\hline$>2001$ & $0 \%$ & $0 \%$ & $0 \%$ & $0 \%$ & $0 \%$ & $0 \%$ & $0 \%$ & $0 \%$ & $0 \%$ & $0 \%$ & $9 \%$ & $0 \%$ & $77 \%$ & $15 \%$ \\
\hline
\end{tabular}

Table 5 - DG2019 exposure matrix derived by Cartis-based inventory, for Veneto region.

\begin{tabular}{|c|c|c|c|c|c|c|c|c|c|c|c|c|c|c|}
\hline & \multicolumn{2}{|c|}{$\begin{array}{c}\text { Vaults with or w/o tie } \\
\text { rods }\end{array}$} & \multicolumn{4}{|c|}{$\begin{array}{l}\text { Beams with } \\
\text { Flexible slab }\end{array}$} & \multicolumn{4}{|c|}{$\begin{array}{c}\text { Beams with } \\
\text { Semi-rigid slab }\end{array}$} & \multicolumn{4}{|c|}{$\begin{array}{c}\text { Beams with } \\
\text { Rigid slab }\end{array}$} \\
\hline & \multirow[t]{2}{*}{$\begin{array}{c}\text { Irregular } \\
\text { layout or } \\
\text { poor } \\
\text { quality }\end{array}$} & \multirow[t]{2}{*}{$\begin{array}{c}\text { Regular } \\
\text { layout or } \\
\text { good } \\
\text { quality }\end{array}$} & \multicolumn{2}{|c|}{$\begin{array}{l}\text { Irregular layout } \\
\text { or poor quality }\end{array}$} & \multicolumn{2}{|c|}{$\begin{array}{c}\text { Regular layout } \\
\text { or } \\
\text { good quality }\end{array}$} & \multicolumn{2}{|c|}{$\begin{array}{l}\text { Irregular layout } \\
\text { or poor quality }\end{array}$} & \multicolumn{2}{|c|}{$\begin{array}{l}\text { Regular layout } \\
\text { or good quality }\end{array}$} & \multicolumn{2}{|c|}{$\begin{array}{l}\text { Irregular layout } \\
\text { or poor quality }\end{array}$} & \multicolumn{2}{|c|}{$\begin{array}{l}\text { Regular layout } \\
\text { or good quality }\end{array}$} \\
\hline & & & $\begin{array}{c}W / 0 \text { tie } \\
\text { rods or } \\
\text { tie } \\
\text { beams } \\
4 \mathrm{~B}\end{array}$ & $\begin{array}{c}\text { With } \\
\text { tie } \\
\text { rods or } \\
\text { tie } \\
\text { beams } \\
4 \mathrm{C}\end{array}$ & $\begin{array}{c}\text { W/o tie } \\
\text { rods or } \\
\text { tie } \\
\text { beams } \\
\text { 4D }\end{array}$ & $\begin{array}{c}\text { With } \\
\text { tie } \\
\text { rods or } \\
\text { tie } \\
\text { beams } \\
4 \mathrm{E}\end{array}$ & $\begin{array}{c}\text { W/o tie } \\
\text { rods or } \\
\text { tie } \\
\text { beams } \\
5 \mathrm{~B}\end{array}$ & $\begin{array}{c}\text { With } \\
\text { tie } \\
\text { rods or } \\
\text { tie } \\
\text { beams } \\
5 \mathrm{C}\end{array}$ & $\begin{array}{c}\text { W/o tie } \\
\text { rods or } \\
\text { tie } \\
\text { beams } \\
\text { 5D }\end{array}$ & $\begin{array}{c}\text { With } \\
\text { tie } \\
\text { rods or } \\
\text { tie } \\
\text { beams } \\
5 E\end{array}$ & $\begin{array}{c}\mathrm{W} / \mathrm{o} \text { tie } \\
\text { rods or } \\
\text { tie } \\
\text { beams } \\
6 \mathrm{~B}\end{array}$ & $\begin{array}{l}\text { With } \\
\text { tie } \\
\text { rods or } \\
\text { tie } \\
\text { beams } \\
6 \mathrm{C}\end{array}$ & $\begin{array}{c}\text { W/o tie } \\
\text { rods or } \\
\text { tie } \\
\text { beams } \\
\text { 6D }\end{array}$ & $\begin{array}{c}\text { With } \\
\text { tie } \\
\text { rods or } \\
\text { tie } \\
\text { beams } \\
6 \mathrm{E}\end{array}$ \\
\hline$<19$ & $0 \%$ & $2 \%$ & $35 \%$ & $12 \%$ & $24 \%$ & $16 \%$ & $1 \%$ & $0 \%$ & $0 \%$ & $0 \%$ & $4 \%$ & $1 \%$ & $3 \%$ & $2 \%$ \\
\hline $19-45$ & $1 \%$ & $1 \%$ & $15 \%$ & $7 \%$ & $24 \%$ & $17 \%$ & $0 \%$ & $0 \%$ & $0 \%$ & $0 \%$ & $9 \%$ & $5 \%$ & $12 \%$ & $8 \%$ \\
\hline $46-61$ & $0 \%$ & $0 \%$ & $0 \%$ & $0 \%$ & $3 \%$ & $5 \%$ & $0 \%$ & $0 \%$ & $0 \%$ & $0 \%$ & $4 \%$ & $11 \%$ & $32 \%$ & $45 \%$ \\
\hline $62-71$ & $0 \%$ & $0 \%$ & $0 \%$ & $1 \%$ & $2 \%$ & $1 \%$ & $0 \%$ & $1 \%$ & $0 \%$ & $0 \%$ & $4 \%$ & $12 \%$ & $45 \%$ & $33 \%$ \\
\hline $72-81$ & $0 \%$ & $0 \%$ & $0 \%$ & $0 \%$ & $0 \%$ & $0 \%$ & $0 \%$ & $0 \%$ & $0 \%$ & $0 \%$ & $1 \%$ & $27 \%$ & $48 \%$ & $23 \%$ \\
\hline $82-91$ & $0 \%$ & $0 \%$ & $0 \%$ & $0 \%$ & $0 \%$ & $0 \%$ & $0 \%$ & $0 \%$ & $0 \%$ & $0 \%$ & $2 \%$ & $5 \%$ & $58 \%$ & $35 \%$ \\
\hline $\begin{array}{c}92- \\
2001\end{array}$ & $0 \%$ & $0 \%$ & $0 \%$ & $0 \%$ & $0 \%$ & $0 \%$ & $0 \%$ & $0 \%$ & $0 \%$ & $0 \%$ & $2 \%$ & $15 \%$ & $65 \%$ & $18 \%$ \\
\hline$>2001$ & $0 \%$ & $0 \%$ & $0 \%$ & $0 \%$ & $0 \%$ & $0 \%$ & $0 \%$ & $0 \%$ & $0 \%$ & $0 \%$ & $0 \%$ & $0 \%$ & $100 \%$ & $0 \%$ \\
\hline
\end{tabular}

For Veneto region, irregular structures represent a significant percentage for older masonry buildings $(<1919)$, but after 1950 almost the whole masonry buildings structures are regular layout structures with rigid floors (see Table 5). According to RO2020 model, it can be noted that for Tuscany region the differences between the original matrix and the recalibrated ones mostly concern masonry structures built between 1919 and 1945 and between 1946 and 1961, with many low-rise buildings classified in more vulnerable classes (Table 6). For Veneto a different distribution of older masonry buildings can be observed, with lower number of them classified as A (Table 7). 
Table 6 - RO2020 Exposure matrix derived from Cartis-based inventory for Tuscany region.

\begin{tabular}{ccccccc} 
Class of height & \multicolumn{3}{c}{ Low } & \multicolumn{3}{c}{ Medium-High } \\
\hline Vulnerability class & A-L & B-L & C1-L & A-MH & B-MH & C1-MH \\
\hline$<\mathbf{1 9}$ & $92 \%$ & $6 \%$ & $2 \%$ & $90 \%$ & $8 \%$ & $2 \%$ \\
$\mathbf{1 9 - 4 5}$ & $85 \%$ & $11 \%$ & $4 \%$ & $85 \%$ & $9 \%$ & $5 \%$ \\
$\mathbf{4 6 - 6 1}$ & $68 \%$ & $19 \%$ & $14 \%$ & $70 \%$ & $15 \%$ & $15 \%$ \\
$\mathbf{6 2 - 7 1}$ & $19 \%$ & $15 \%$ & $66 \%$ & $14 \%$ & $20 \%$ & $65 \%$ \\
$\mathbf{7 2 - 8 1}$ & $17 \%$ & $17 \%$ & $66 \%$ & $10 \%$ & $22 \%$ & $67 \%$ \\
$\mathbf{8 2 - 9 1}$ & $8 \%$ & $11 \%$ & $81 \%$ & $17 \%$ & $3 \%$ & $80 \%$ \\
\hline
\end{tabular}

Table 7 - RO2020 Exposure matrix derived from Cartis-based inventory for Veneto region.

\begin{tabular}{|c|c|c|c|c|c|c|}
\hline \multirow{2}{*}{$\begin{array}{c}\text { Class of height } \\
\text { Vulnerability class }\end{array}$} & \multicolumn{3}{|c|}{ Low } & \multicolumn{3}{|c|}{ Medium-High } \\
\hline & A-L & B-L & C1-L & A-MH & B-MH & C1-MH \\
\hline$<19$ & $51 \%$ & $29 \%$ & $21 \%$ & $52 \%$ & $24 \%$ & $24 \%$ \\
\hline $19-45$ & $24 \%$ & $38 \%$ & $38 \%$ & $38 \%$ & $24 \%$ & $38 \%$ \\
\hline $46-61$ & $0 \%$ & $19 \%$ & $81 \%$ & $9 \%$ & $8 \%$ & $83 \%$ \\
\hline $62-71$ & $4 \%$ & $6 \%$ & $90 \%$ & $9 \%$ & $19 \%$ & $72 \%$ \\
\hline $72-81$ & $0 \%$ & $2 \%$ & $98 \%$ & $1 \%$ & $46 \%$ & $53 \%$ \\
\hline $82-91$ & $2 \%$ & $8 \%$ & $91 \%$ & $1 \%$ & $3 \%$ & $95 \%$ \\
\hline
\end{tabular}

\subsection{Damage and Risk assessment}

The effects of a different vulnerability characterization at regional scale is evaluated with the aid of IRMA platform [12]. In the platform, different exposure/vulnerability models (VEM) and different sets of fragility curves can be employed. Deriving the exposure data from ISTAT 2011 database, the VEM is defined by an exposure matrix that identifies rules to classify the building typologies, derived by census data, into vulnerability classes adopted by the model. Using DG2019 approach the VEM is simply defined by building classes for age of construction, that are combined with the age-dependent fragility curves. In RO2020 approach, the VEM is defined by exposure matrix that provides the occurrence percentage of building classes (for age of construction and class of height) in the vulnerability classes identified in the model (A, B, C1), combined with the relative fragility curves. The improvement provided by the proposed procedure is evaluated comparing the outcomes of damage and risk assessment obtained by the adoption of the original set of age-dependent fragility curves and the exposure matrix, respectively for DG2019 and RO2020 model, with results obtained after the recalibration procedure.

Unconditional damage and risk assessment for 50 years timeframe is performed, that is an assessment obtained considering the probability of ground shaking severity in a selected time observation window according to PSHA based methodology. As both adopted VEM are for masonry buildings, the analyses are performed considering only this typology (masonry). Tables $8,9,10,11$ report the number of buildings for each damage state employing the original model (columns DG or RO) and the updated exposure modelling (columns DG+CA or $\mathrm{RO}+\mathrm{CA}$ ). The difference between the Cartis-based model and the original one is indicated as $\Delta$ and the Regionalization factor RF, that can be considered as a parameter to represent variation in terms of expected damage due to a different exposure modelling, is calculated as the ratio of $\Delta$ versus DG or RO, respectively for DG2019 and RO2020 model. 
Table 8 - Number of buildings for each damage state, adopting the original exposure matrix DG2019 (DG) and the re-calibrated one based on CARTIS data (CARTIS) for Tuscany region.

\begin{tabular}{ccccc} 
& DG & DG+CA & $\boldsymbol{\Delta}$ & RF \\
\hline DS0 & 138784 & 126798 & -11986 & $-9 \%$ \\
DS1 & 133272 & 123662 & -9610 & $-7 \%$ \\
DS2 & 59770 & 58576 & -1194 & $-2 \%$ \\
DS3 & 81715 & 86155 & 4440 & $5 \%$ \\
DS4 & 88598 & 95497 & 6899 & $8 \%$ \\
DS5 & 46010 & 57462 & 11452 & $25 \%$ \\
\hline
\end{tabular}

Table 9 - Number of buildings for each damage state, adopting the original exposure matrix RO2020 (RO) and the re-calibrated one based on CARTIS data (CARTIS) for Tuscany region.

\begin{tabular}{ccccc} 
& RO & RO+CA & $\boldsymbol{\Delta}$ & RF \\
\hline DS0 & 374663 & 340104 & -34560 & $-9 \%$ \\
DS1 & 101790 & 111078 & 9288 & $9 \%$ \\
DS2 & 30561 & 41503 & 10942 & $36 \%$ \\
DS3 & 20040 & 26479 & 6439 & $32 \%$ \\
DS4 & 15714 & 21567 & 5853 & $37 \%$ \\
DS5 & 5381 & 7419 & 2038 & $38 \%$ \\
\hline
\end{tabular}

TUSCANY - Regionalization Factors

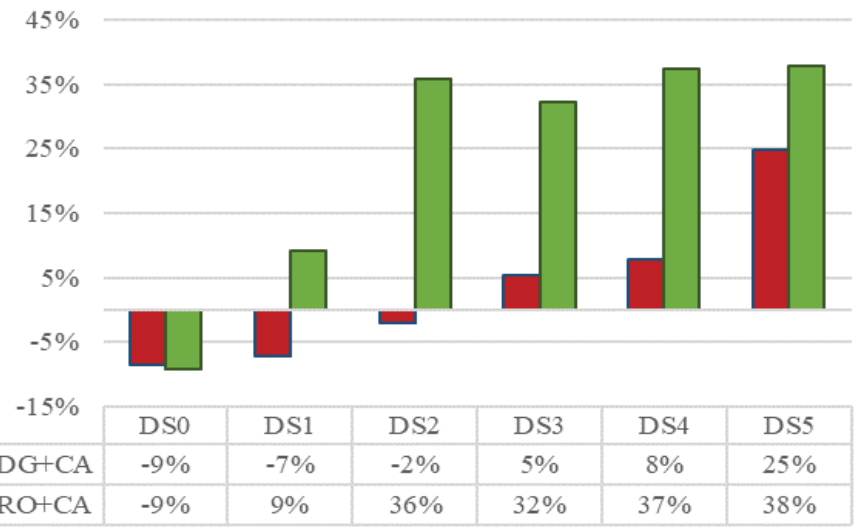

Figure 4 - The variation of number of buildings in each damage state with respect to the original model (i.e. the RF) obtained adopting the Cartis-based procedure (DG+CA for DG2019 and RO+CA for RO2020 model) for Tuscany region.

For Tuscany region, an increased number of building having medium-high damage states (DS3, DS4, DS5) can be observed according to Cartis-based model. Using DG2019 approach, the number of buildings that reach the heaviest damage grade (DS5) increases by $+25 \%$, while for the lower damage levels lower variations can be observed (see Figure 4). In reverse, adopting RO2020 model, with Cartis-based approach the numbers of buildings significantly increase for most of damage levels, with a value of RF grader than $+30 \%$ from DS 2 to DS5. This significant difference from DG2019 and RO2020 model is probably due to the different classification criteria. Indeed, according to RO2020 all the masonry buildings with irregular texture are classified as class A, the most vulnerable class, while in DG2019 different classes are identified for irregular layout buildings based on the horizontal structures type, to which different vulnerability level as well as fragility functions are associated. Therefore, for example, if for the second model irregular layout structures with rigid slab are less vulnerable than irregular layout structure without tie roads or tie beams with vaults, according to first one 
these building are clustered in an unique class, the most vulnerable class A, greatly influencing the damage distribution.

For Veneto, a decrement of damaged buildings can be observed. Assuming the RF value for DS2 as reference, as it is representative of moderate damage, it can be observed a value of $-30 \%$ according to DG2019 and $-26 \%$ for RO2020. Differently to Tuscany region, for Veneto the presence of a small number of irregular layout structures, widespread only among oldest masonry building, leads to similar value of RF for both models (see Figure 5).

Table 10 - Number of buildings for each damage state, adopting the original exposure matrix DG2019 (DG) and the re-calibrated one based on CARTIS data (CARTIS) for Veneto region.

\begin{tabular}{ccccc} 
& DG & DG+CA & $\boldsymbol{\Delta}$ & RF \\
\hline DS0 & 411779 & 504687 & 92907 & $23 \%$ \\
DS1 & 175772 & 145021 & -30751 & $-17 \%$ \\
DS2 & 55532 & 39056 & -16477 & $-30 \%$ \\
DS3 & 60906 & 39197 & -21709 & $-36 \%$ \\
DS4 & 55843 & 34638 & -21205 & $-38 \%$ \\
DS5 & 26863 & 24098 & -2765 & $-10 \%$ \\
\hline
\end{tabular}

Table 11 - Number of buildings for each damage state, adopting the original exposure matrix RO2020 (RO) and the re-calibrated one based on CARTIS data (CARTIS) for Veneto region.

\begin{tabular}{ccccc} 
& RO & RO+CA & $\boldsymbol{\Delta}$ & RF \\
\hline DS0 & 652750 & 673175 & 20425 & $3 \%$ \\
DS1 & 85160 & 78056 & -7104 & $-8 \%$ \\
DS2 & 19676 & 14530 & -5146 & $-26 \%$ \\
DS3 & 13587 & 10010 & -3576 & $-26 \%$ \\
DS4 & 11031 & 7792 & -3239 & $-29 \%$ \\
DS5 & 4493 & 3132 & -1361 & $-30 \%$ \\
\hline
\end{tabular}

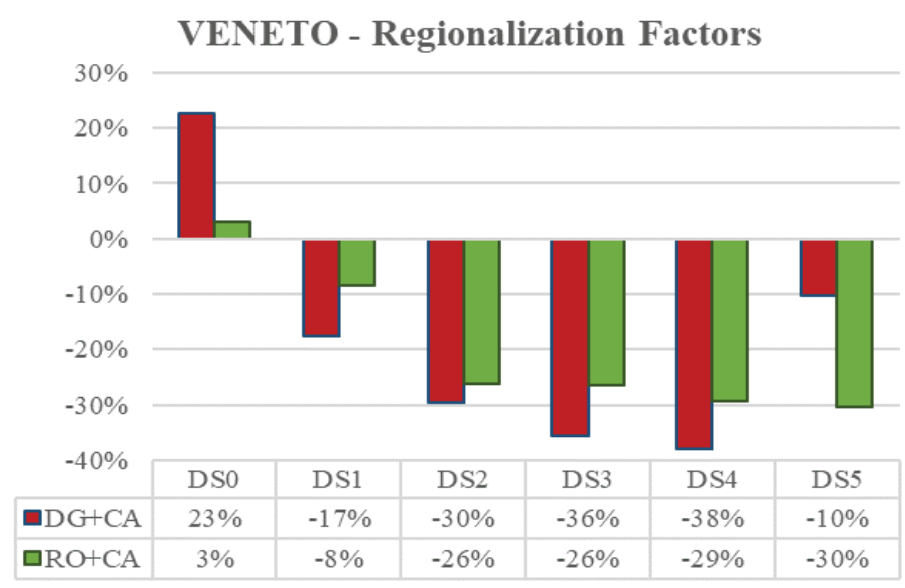

Figure 5 - The variation of number of buildings in each damage state with respect to the original model (i.e. the RF) obtained adopting the Cartis-based procedure (DG+CA for DG2019 and RO+CA for RO2020 model) for Veneto region.

The seismic risk in terms of economic losses is calculated, as well. In IRMA, the impact quantities are provided as a function of expected number of buildings affected by different damage level, according to the consequences model adopted in the recent national risk assessment for Italy (Dolce et al. 2020). The mean value of losses $/ \mathrm{m}^{2}$ among all the municipalities in each region is calculated and chosen as regional loss indicator. Likewise to what done previously, the regionalization factor due to losses RF_L is evaluated. 
Table 12 - Values of economic losses for each region analyzed, according to the different models adopted (DG2019 and the one recalibrated by Cartis-based approach).

\begin{tabular}{lccrc}
\cline { 2 - 5 } & $\begin{array}{c}\text { L_DG/mq } \\
{[\boldsymbol{\epsilon} / \mathbf{m q}]}\end{array}$ & $\begin{array}{c}\text { L_CARTIS/mq } \\
{[\boldsymbol{\epsilon} / \mathbf{m q}]}\end{array}$ & $\Delta[\boldsymbol{\Delta} / \mathbf{m q}]$ & $\mathbf{R F}_{-} \mathbf{L}$ \\
\cline { 2 - 5 } TOSCANA & 566.9 & 621.1 & 54.2 & $\mathbf{0 . 1 0}$ \\
VENETO & 267.8 & 186.0 & -81.8 & $\mathbf{- 0 . 3 1}$ \\
\cline { 2 - 5 }
\end{tabular}

Table 13 - Values of economic losses for each region analyzed, according to the different models adopted ( $\mathrm{RO} 2020$ and the one recalibrated by Cartis-based approach).

\begin{tabular}{ccccc}
\cline { 2 - 5 } & $\begin{array}{c}\text { L_RO/mq } \\
{[\boldsymbol{\epsilon} / \mathbf{m q}]}\end{array}$ & $\begin{array}{c}\text { L_CARTIS/mq } \\
{[\boldsymbol{\epsilon} / \mathbf{m q}]}\end{array}$ & $\Delta[€ / \mathbf{m q}]$ & RF_L \\
\cline { 2 - 5 } TOSCANA & 135.5 & 182.7 & 47.2 & $\mathbf{0 . 3 5}$ \\
VENETO & 65.1 & 50.3 & -14.8 & $\mathbf{- 0 . 2 3}$ \\
\cline { 2 - 5 }
\end{tabular}

\section{CONCLUSIONS}

The methodology proposed in [22] is adopted in this study to evaluate the effects of adopting improved exposure modelling on risk analysis. Cartis database is used to re-calibrate models relative to two existing empirical vulnerability models (DG2019 [3] and RO2020 [23]) for two Italian regions, Tuscany and Veneto. It is worth noting that this is a preliminary study about regional vulnerability characterization as the proposed exposure models are calibrated on the available Cartis' data on a limited number of municipalities in each region. However, the re-calibration procedure here proposed allows to detect the potential change in vulnerability region by region.

The main outcomes of the adopted approach can be summarized as follows:

- The use of Cartis-based approach leads to different distributions of building typologies at regional scale with respect to exposure models commonly calibrated on the base of empirical data derived on areas recently struck by an earthquake.

- The use of different exposure models at regional level has a significant influence on the damage assessment, also depending on the adopted vulnerability model. To assess such influence a parameter, the regionalization factor RF, may be defined to account for differences in damage assessment due to the use of improved exposure models with respect to original one. The RF referred to an intermediate damage state DS3 for Tuscany region is quite low adopting DG2019 model (5\%), while assumes a value of $+32 \%$ using RO2020 model. The reason of this discrepancy is probably due to the different vulnerability classification proposed by the models, that influence the damage distribution mostly for the regions where irregular layout structures are largely widespread.

- The influence of different exposure modelling at regional scale on economic losses can be effectively represented by regionalization factor associated to economic losses RF_L. RF_L may be used for a synthetic representation of the variation of risk estimation that can be obtained with improved exposure characterization.

As this study represents a first application toward the regional exposure assessment, the results obtained provide just a trend about vulnerability and risk at regional level and they can be improved when more data become available. 


\section{ACKNOWLEDGMENTS}

This study was performed within the framework of the PE2019-2021 joint program DPCReLUIS, WP2: "Inventory of existing building typologies" and WP4 "Risk maps and seismic damage scenarios".

\section{REFERENCES}

[1] G. Grünthal European Macroseismic Scale, Chaiers du Centre Européen de Géodynamique et de Séismologie, Luxembourg, vol. 15, 1998.

[2] F. Braga, M. Dolce, D. Liberatore, A statistical study on damaged buildings and an ensuing review of the MSK-76 scale, 1982, In Proceedings of the seventh European conference on earthquake engineering, Athens, Greece , 431-450, 1982.

[3] C. Del Gaudio, G. De Martino, M. Di Ludovico, G. Manfredi, A. Prota, P. Ricci, GM Verderame, Empirical fragility curves for masonry buildings after the 2009 L'Aquila, Italy, earthquake. Bull Earthq Eng 17(11):6301-6330, 2019.

[4] M. Rota, A. Penna, C.L. Strobbia, Processing Italian damage data to derive typological fragility curves. Soil Dyn Earthq Eng 28(10):933-947, 2008.

[5] M. Pagani, J. Garcia-Pelaez, R. Gee, K. Johnson, V. Poggi, R. Styron, G. Weatherill, M. Simionato, D. Viganò, L. Danciu, D. Monelli, Global Earthquake Model (GEM) Seismic Hazard Map (version 2018.1 - December 2018), DOI: 10.13117/GEM-GLOBALSEISMIC-HAZARDMAP- 2018.1, 2018.

[6] R. Spence, R. Foulser-Piggott, A. Pomonis, H. Crowley, P. Gue'guen, A. Masi, L. Chiauzzi, G. Zuccaro, F. Cacace, C. Zulfikar, M. Markus, D. Schaefer, M.L. Sousa, A. Kappos, The European building stock inventory: creating and validating a uniform database for earthquake risk modeling and validating a uniform database for earthquake risk modeling risk modeling. In: The 15th world conference on earthquake engineering, Lisbon, Portugal, Sept 2012.

[7] H. Crowley, V. Despotaki, D. Rodrigues, V. Silva, D. Toma-Danila, E. Riga, A. Karatzetzou, S. Fotopoulou, Z. Zugic, L. Sousa, S. Ozcebe, P. Gamba, Exposure model for European seismic risk assessment. Earthquake Spectra; DOI: 10.1177/8755293020919429, 2020.

[8] M. Polese, M. Gaetani d'Aragona, A. Prota, Simplified approach for building inventory and seismic damage assessment at the territorial scale: an application for a town in southern Italy. Soil dynamics and earthquake engineering, 121:405-420, 2019.

[9] M. Polese, M. Di Ludovico, M. Gaetani d'Aragona, A. Prota, G. Manfredi, Regional vulnerability and risk assessment accounting for local building typologies, International Journal of Disaster Risk Reduction, 43: 141400, 2020.

[10] M. Polese, M. Di Ludovico, A. Prota, G. Tocchi, M. Gaetani d'Aragona, The use of Cartis form for inventory updating and effects on the vulnerability estimations at the territorial scale, XVIII 25 Convegno Nazionale "L'Ingegneria Sismica in Italia", Paper ID 3508, Ascoli Piceno, September 2019 (in Italian). 
[11] M. Dolce, A. Prota, B. Borzi, F. da Porto, S. Lagomarsino, G. Magenes, C. Moroni, A. Penna, M. Polese, E. Speranza, G.M. Verderame, G. Zuccaro, Seismic risk assessment of residential buildings in Italy. Bull Earthquake Eng. https://doi.org/10.1007/s10518020-01009-5, 2020.

[12] B. Borzi, M. Onida, M. Faravelli, D. Polli, M. Pagano, D. Quaroni, A. Cantoni, E. Speranza, C. Moroni, IRMA platform for the calculation of damages and risks of residential buildings. Bulletin of Earthquake Engineering, DOI: 10.1007/s10518-02000924-x, 2020.

[13] A. Lucantoni, V. Bosi, F. Bramerini, R. De Marco, T. Lo Presti, G. Naso, F. Sabetta, Il rischio sismico in Italia. Ingegneria Sismica, 1, 5-35, 2001.

[14] G. Di Pasquale, G. Orsini, R.W. Romeo, New developments in seismic risk assessment in Italy. Bull Earthq Eng 3:101-128, 2005.

[15] F. Cacace, G. Zuccaro, D. De Gregorio, F.L. Perelli, Building Inventory at National scale by evaluation of seismic vulnerability classes distribution based on Census data analysis: BINC procedure. International Journal of Disaster Risk Reduction, 28, pp. 384-393, 2018.

[16] A. Bernardini, S. Lagomarsino, A. Mannella, A. Martinelli, L. Milano, S. Parodi, Forecasting seismic damage scenarios of residential buildings from rough inventories: a case-study in the Abruzzi Region (Italy). Proc. IMech E Part O: J. Risk and Reliability, 224: 279-296, 2010.

[17] M. Dolce, A. Goretti, Building damage assessment after the 2009 Abruzzi earthquake. Bull Earthq Eng 13(8):2241-2264, 2015.

[18] F. Salmoiraghi F, Materiali naturali da costruzione, Milano, 1892.

[19] F. Rodolico, Le pietre delle città d'Italia, Le Monnier, Firenze, 1965.

[20] G. Zuccaro, M. Della Bella, F. Papa, Caratterizzazione tipologico strutturali a scala nazionale. Atti $9^{\circ}$ Convegno Nazionale ANIDIS, L'ingegneria Sismica in Italia, Torino, 1999 (in Italian).

[21] G. Zuccaro, M. Dolce, D. De Gregorio, E. Speranza, C. Moroni, La scheda CARTIS per la caratterizzazione tipologico- strutturale dei comparti urbani costituiti da edifici ordinari. Valutazione dell'esposizione in analisi di rischio sismico; In: Proceedings of GNGTS, 2015.

[22] G. Tocchi, M. Polese, M. Di Ludovico, A. Prota, Regional based exposure models to account for local building typologies. Bull Earthq Eng (submitted).

[23] A. Rosti, M. Rota, A. Penna, Empirical fragility curves for Italian URM buildings. Bulletin of Earthquake Engineering, DOI: 10.1007/s10518-020-00845-9, 2020.

[24] M. Pagani, D. Monelli, G. Weatherill, L. Danciu, H. Crowley, V. Silva, M. Simionato, OpenQuake engine: an open hazard (and risk) software for the global earthquake model. Seismol Res Lett 85(3):692-702, 2014.

[25] M. Stucchi, A. Akinci, E. Faccioli, P. Gasperini, L. Malagnini, C. Meletti, V. Montaldo, G. Valensise, Mappa di Pericolosità sismica del territorio Nazionale http://zones ismic he.mi.ingv.it/docum enti/ rappo rto_concl usivo .pdf, 2004 (in italian) 
[26] M. Stucchi, C. Meletti, V. Montaldo, H. Crowley, G.M. Calvi, E. Boschi, Seismic hazard assessment (2003-2009) for the Italian building code. Bull Seism Soc of Am 101:1885-1911, 2011. 